\title{
Microtubule Process
}

National Cancer Institute

\section{Source}

National Cancer Institute. Microtubule Process. NCI Thesaurus. Code C40798.

Any cytoskeletal process involving microtubule structures and their associated proteins. 